DOI: $\square$ https://doi.org/10.15407/techned2020.04.076

\title{
THE INFLUENCE OF ELECTRICAL ENERGY QUALITY TO ECONOMIC CHARACTERISTICS OF ISOLATED MICROGRID
}

\author{
Journal \\ Publisher \\ ISSN \\ Issue \\ Pages
}

\author{
Tekhnichna elektrodynamika \\ Institute of Electrodynamics National Academy of Science of Ukraine \\ 1607-7970 (print), 2218-1903 (online) \\ No 4, 2020 (July/August) \\ $76-79$
}

\author{
Authors \\ Yamnenko Y.S.*, Tereshchenko T.O.**, Fedin I.S.***, Klepach L.E.**** \\ National Technical University of Ukraine "Igor Sikorsky Kyiv Polytechnic Institute", \\ Peremohy ave., 37, 03056, Kyiv, Ukraine, \\ e-mail: tereshchenko50.t.a@gmail.com \\ * ORCID ID : https://orcid.org/0000-0002-9796-6420 \\ ** ORCID ID : https://orcid.org/0000-0003-4009-2854 \\ *** ORCID ID : https://orcid.org/0000-0003-0264-5067 \\ **** ORCID ID : https://orcid.org/0000-0002-3026-3755
}

\section{Abstract}

The impact of quality parameters of electrical energy to the economic characteristics of distributed generation systems, in particular on the profits from renewable power sources in isolated islanded MicroGrid, has been investigated. For this purpose, the Lagrange method was used to solve the task of profit maximization taking into account the limitations of the power supply system at different values of efficiency factors and nonlinear distortions of the AC supply load. The initial data for this task includes, in addition to the number of generators, loads and characteristics of their modes, also the forecasted values of consumption/generation and the local "conditional" cost of renewable energy sources. The result of the solution is the determination of generator coefficients and loads at each interval of the daily chart. The obtained coefficients determine on/off state or share of energy on which the power supply system element is working in the interval. These resulting values are used as the basis of the algorithm to control MicroGrid system by cost criterion. References 7, figure 1. 
Key words: islanded MicroGrid, distributed generation systems, renewable energy sources, efficiency factors and nonlinear distortions.

Received: 28.02.2020

Accepted: 06.05.2020

Published: 26.06.2020

\section{References}

1. Taking Stock of Leading Innovators in Global Remote Microgrid Markets. MGP Newsletter. 2019. URL: https://minigrids.org/taking-stock-of-leading-innovators-in-global-remote-microgridmarkets/

2. Zhuikov V., Yamnenko J., Tereschenko T., Klepach L., Boiko I. Static and Dynamic Tariffing Electric Power Autonomous Microgrid. Journal of Present Problems of Power System Control, Scientific Papers of the Department of Electrical Power Engineering of Wroclaw University of Technology 2016. No 7. Pp. 29-41. URL: http://yadda.i cm.edu.pl/baztech/element/bwmeta1 .element.baztech-74a78806-232d-49fa-a1f0-e91d6662ea $\underline{0 \mathrm{~d}}$

3. Klepach L. Power consumption management according to technical and economic indicators. VIII International Scientific and Technical Conference of Young Scientists Electronics-2015 . Kyiv. 2015. Pp. 227-231 (Ukr) URL: http://elconf.kpi.ua/wp-conte nt/uploads/2016/03/ELCONF-2015.pdf

4. Akulich I.L. Mathematical programming in examples and tasks. Moskva: Vysshaya shkola, 1986. 319 p. (Rus)

5. DBN V.2.5-23:2010. Design of electrical equipment for civil purposes. (Rus) URL: http://kb u.org.ua/assets/app/documents/dbn2/92.1

6. Tereshchenko T.O., Yamnenko Yu.S., Laikova L.H., Fedin I.S. Method of forming three-phase voltage. Patent of Ukraine. No 136713. 2019 (Ukr) URL: https://sis.ukrpatent.org/u $\mathrm{k} / \mathrm{search} /$ detail/1374162/

7. Pivniak H.H., Zhezhelenko I.V., Papaika Yu.A. Energy efficiency of power supply systems. Dnipro: NTU DP, 2018. 148 p. (Ukr) 


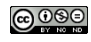

This work is licensed under a Creative Commons Attribution-NonCommercial-NoDerivatives $\underline{4.0 \text { International License }}$ 